Article

\title{
Theology as an Ethnographic Object: An Anthropology of Eastern Christian Rupture
}

\author{
Timothy Carroll \\ Department of Anthropology, University College London, London WC1E 6BT, UK; t.carroll@ucl.ac.uk \\ Received: 31 March 2017; Accepted: 19 June 2017; Published: 26 June 2017
}

\begin{abstract}
This paper draws upon over three years' research among Eastern Orthodox (principally Antiochian and Greek) communities in London and Mount Athos, Greece. This research came to engage theology quite heavily as part of the ethnographic facts of the fieldsites. This paper reviews some of the existing ways that theology (as both discipline and practice) relate to ethnographic enquiry, particularly as it has arisen in the dialogue with the Anthropology of Christianity and frames this in light of the historical development of Anthropology and its relationship to theology and Christianity. The paper then advances a methodological argument, in favour of further means of relation, specifically in terms of theology as a cultural artefact. Drawing on local practices of liturgical theology and Eastern Orthodox forms of allegorical interpretation, I argue for the inclusion of theological insight and practice within the social scientific study of religion. Working in an Orthodox setting requires the investigation of liturgical theology and brings to light important aspects of the relationship between temporal and sempiternal domains of action. Particularly as it relates to liturgical theology and the practices of interpretation, ethnographic enquiry into Orthodox theology asks for a reconsideration of social scientific methods of analysis and representation.
\end{abstract}

Keywords: anthropology; theology; Orthodox Christianity

\section{Introduction}

Over the course of ethnographic research ${ }^{1}$ amongst Eastern Orthodox Christians, based primarily in London and Mount Athos amongst Antiochian and Greek Orthodox communities, I was routinely pointed to theology. During interviews and informal conversations, informants regularly appealed to theology - even when I was not asking pointedly 'theological' questions. Priest and laywoman alike would quote (or more often paraphrase) works of both ancient and modern theology. Even those who readily acknowledged a lack of theological insight actively engaged in discussions about theology, either with clergy or fellow parishioners. Whenever the community gathered for various events or a post-liturgy coffee there was certain to be at least some theological dialogue. In public settings, such as when circled around tables at the hotel coffee house around the corner from the local parish, this dialogue was usually led by the priest in something that fluctuated between a Q\&A session and a mini-lecture. In other settings, amongst pilgrims on Mount Athos, for example, or over lunch, casual exchange of theology also regularly took place.

Because of this omnipresence of theology-not only as a formal disciplinary practice but also as a liturgical practice and sort of lay devotion, I found it essential to the integrity of my ethnographic method to interact regularly and critically with the theology I witnessed during my research. This choice was, however, difficult to justify in some social scientific circles, as engaging theology in such a manner pushes the boundaries of Anthropological enquiry.

1 Research was principally carried out between September 2009 and August 2012. Subsequent research visits have been conducted at regular intervals since. 
Joel Robbins, an anthropologist who has written extensively on the relationship between Theology and Anthropology, admits that part of the disciplinary hesitancy to read theology may be born 'of a still lingering reluctance to study elites' (Robbins 2006, p. 286). However, when theology is something present in the fieldsite, being used, discussed, and engaged with by individuals who are clearly not 'elites', a reappraisal of what theology is within ethnographic practice is necessary.

The methodological argument presented in this paper opens with a historical overview of the relationship between Anthropology as a discipline and Christianity, in order to frame how Anthropological enquiry currently engages theology ${ }^{2}$. The paper then proposes a new approach, and offers a case study whereby the reading of Orthodox theology and an examination of Orthodox liturgical practice opens up new insight into how social scientific enquiry may best use theology as an ethnographic object.

\section{Anthropology and Christianity}

In a co-written article on the Anthropology of Christianity published in 2008, Jon Bialecki, Naomi Haynes and Joel Robbins argue that 'Within the past decade, a comparative, self-conscious anthropology of Christianity has begun to come into its own' (Bialecki et al. 2008, p. 1139) ${ }^{3}$. But there is ample evidence of good ethnography and anthropological debate about Christianity stretching back well before 1998, including classic anthropological texts by those such as Bond et al. (1979), Brandes (1980), Campbell (1964), Christian (1972), Comaroff and Comaroff (1991), Ingham (1986), Stewart (1991), Turner and Turner (1995), Visvanathan (1993), and Wilson (1971). The hinge in the authors' claim is the self-conscious part.

The Anthropology of Christianity had become self-conscious in two primary ways in the preceding decade. One is a simple matter of sub-disciplinary development, and the second has wider reaching impact on how Anthropology has developed as a discipline and will impact how it moves forward, particularly in its relation to other disciplines such as that of Theology. I first address the two ways in which the Anthropology of Christianity can be described as 'self-conscious', and then focus the paper on the role of theology within ethnographic practice.

The most obvious indication of self-consciousness is that the discipline now speaks of the Anthropology of Christianity', and whether the speaker thinks it is indeed new and good, or a hollow project of self-promotion, it has, unquestionably, produced considerable discussion and literature. Further evidence to suggest that the subfield exists in a robust manner is seen in that there are people writing against it (Hann 2007, 2011, 2012) and expressing what might be seen as its identity crisis (Robbins 2013). The debate concerning the validity and nature of the subdiscipline brings to the fore the next aspect of Anthropology of Christianity as 'self-conscious'.

Many voices in the discourses surrounding Anthropology of Christianity are apprehensive of the relationship between Christianity and Anthropology. Asad (1993) argument that conceptions of religion have been coloured by the Christian emphasis on 'belief' is just one example of how fundamental Christian thought is to the discipline (Bialecki et al. 2008, p. 1142). The relationship between Anthropology and Christianity has a curious history. Davies (2002) citing Mary Douglas (1966) highlights some of the contributions made by theologians to the founding of Anthropology. Similarly, much of the discipline's early ethnographic data comes from the Christian missions. Mary Douglas (1966) Purity and Danger as well as her other pieces on Hebrew practice and anthropological concepts such as rites of passage (Douglas 1993, 1999, 2004) have, in reciprocation, entered into

2 It is important to note that this is a rapidly advancing field currently. A helpful resource, including an extensive bibliography, exists at http:/ / research.franklin.uga.edu/tea/ as part of the John Templeton funded project, 'Theologically Engaged Anthropology', led by Derrick Lemons (University of Georgia).

3 Earlier Robbins (2007, though written a few years before) argues that anthropology of Christianity does not yet exist. His introduction to the 2007 paper Continuity of Thinking points to the need for cross-areal comparison, separate from regional or specific theoretical interest. 
Christian discourses shaping Protestant understanding of Old Testament Theology and Missiological understandings of culture and society. Ethnographic practice and missionary work often become interwoven, influencing each other and becoming entangled. Classics of Anthropology, such as Leenhardt (1947), have been produced by missionaries-cum-ethnographers, with great benefit to the discipline. Conversely, as (Keane 2007, p. 101) notes, 'theoretical concern[s]' in the discipline often shape missiological practice. In both cases, the historical trajectory of one cannot be separated from the context of the other.

One might expect the mutual influence between Anthropology and Christian thought and practice to allow for an amicable relationship. This has not, however, been the case. While there is a sizeable shared lexicon, and while theory can pass between the two disciplines with relative ease, Christianity has historically been shunned for several reasons. On first count, there is the simple fact that much of Anthropology's roots come from a fascination with the other, the exotic. Colonial and Missionary encounters with the absurdity of human variation fostered intellectual engagement which then asked for fieldwork in exotic places. Christianity was simply too close to home-even for those who had not grown up with some sort of Christian background (e.g., Durkheim) Christianity was the predominant religion practiced in the society in which they lived, and thus carried a level of analytical normativity (cf. Cannell 2006).

Furthermore, the traditionally secular, and often atheist, methodology under-girding Anthropology met a curious object in Christianity (see Engelke 2002). While one would expect to find commonalities, Christians rather prove to be 'disappointing subalterns', who, as Susan Friend Harding (1991) has noted, do not support the 'right' (that is, left, liberal) political agendas, and who are all too concerned with private devotion (Bialecki et al. 2008, p. 1140). Consequently, they are deemed by the discipline to be 'culturally repugnant others whom it is best to avoid' (Bialecki et al. 2008, p. 1140., cf. Harding 1991; Howell 2007). Because of this, anthropologists have historically tended to ignore or marginalise Christianity, often following Durkheimian or Weberian interpretations reducing Christianity to a social, political or modernising force (Comaroff and Comaroff 1991), being only a product of 'contact' and devoid of substance required to be 'cultural' in its own right (Barker 1992; Chua 2012; Robbins 2004, pp. 27ff). This is a curious and limited take on Christianity, especially considering groups such as the Amish or Syriac Orthodox who can hardly be called modernising, ${ }^{4}$ nor products of 'contact'.

In fact, this anthropological bias also presumes a rather narrow answer to the question: Who are 'Christians'? Cannell, in her 2005 piece on the Latter Day Saints, recounts a few examples of the shock with which she was met when she told secular anthropologists of her research topic. In the reaction, Cannell sees a bias within anthropological discourse to not admit Mormons as 'Christian'. She sees the resistance stemming from the fact that most of the groups addressed within the ethnographic record (to date in 2005) are Roman Catholic, Charismatic, or a Protestant group that can trace its history quite clearly to Reformation thought presented by Luther or Calvin. Most of the Christianities studied are specific products of missionisation done contemporaneously with European colonial presence. This means that the clear majority of Christianities discussed in Anthropology are a particular kind of post-enlightenment take on Augustinian Theology $y^{5}$. This bias within Anthropology toward Protestant and Catholic forms of Christianity bypasses non-Creedal Christianities (such as Latter Day Saints) and non-Western Christianities (such as Eastern and Oriental Orthodox). Over the last decade, however, this bias has started to subside as a result of the growing acceptance of Christianity as a subject of study.

The acceptance of studying 'Christianity as a cultural logic' (Engelke and Tomlinson 2006, p. 19) is a product of two otherwise unrelated trends. In the first case, the middle of the 20th century saw a growing trend in Western Christianity moving to the foreground of public discourse. Contrary to

4 For discussions of Eastern Orthodoxy and its relation to modernity, see Makrides (2012) and Pop (2011).

5 That is, following the writings of Augustine of Hippo (354-430 AD). 
Weber (2005) and Durkheim (1915) anticipated 'decline of traditional religions' (Cannell 2010, p. 86), many churches sought to revitalise their own religious fervour in response to the perceived increase in secularism. By the 1970s, several things had developed. Most noticeably, the Roman Catholic Church, with the Vatican II Council (1962-1965), established that mass should be spoken in the local language ${ }^{6}$ and gave new urgency to missionary work with an emphasis on the idea that Christianity and indigenous culture were not at odds, but rather that Christianity is best when 'inculturated' into the local flavour ${ }^{7}$. Similarly, the decennial Lambeth Conference in 1968 and 1978 marked a shift in the Anglican Communion, recognising the national churches throughout the world-and especially the Global South - to be independent and equal to their mother church, the Church of England. In 1974, a number of-mainly evangelical and European-churches signed the Lausanne Covenant, committing to work together, dedicated to world evangelism and engagement (Stott 1975). In the USA, the increased engagement in politics became unified and recognised as the Moral Majority in 1979 (Harding 2000). On the whole, the fragmented Christian populations in Euro-America saw a need to be more visible in the second half of the last century. ${ }^{8}$ The 1970s and 1980s also saw 'a period of intense revival activity through many parts of Melanesia' (Robbins 2004, p. 122). The rise in Christianity's public presence and activity both in Euro-America and in lands with a long tradition as anthropological grounds of ethnography dovetailed nicely with the introspective trend in Anthropology. The post-modern critique called into question the traditional notions of representation, and anthropologists started to try their techniques of enquiry on groups closer to home and on themselves. Suddenly Christianity became a relevant and safe topic, simultaneously.

Webb Keane (2007) introduction to Christian Moderns provides a particularly well-articulated example of the shifting perception of Christianity within the disciple. Going to Sumba, Indonesia, in 1985, Keane had no intention of studying Christianity, and tended to gloss over it when he encountered it $^{9}$. Finding himself writing a book in which Christianity plays a major role, he says:

Umbu Neka, along with the members of my own Sumbanese household, and several other friends, colleagues, and acquaintances in Sumba, forced me to take their religion seriously and to grapple with the fact that they assumed this was also the religion of tau jiawa kaka (white foreigners) like me. (Keane 2007, p. 29)

Coming to terms with how Christianity must be addressed, he concludes:

As a first principle, in this book I treat Christianity as what Marcel Mauss [in The Gift] would have called 'social fact.' By social fact, I mean simply this: Christianity, its ideas, institutions, social formations, political identities, hopes, desires, fears, norms, and practices, both everyday and extraordinary, exist for an (sic) remarkably large and varied number of people. Christianity may be part of a taken-for-granted background or a fervent frontline concern, the tone of people's engagement may be indifferent or passionate, but for them it is there. (Keane 2007, p. 29, emphasis original)

While Keane was confronted with Christianity in his fieldsite, only with time did he begin to engage with it. This move to study Christianity anthropologically is the final turn toward an Anthropology of Christianity.

\section{Sacrosanctum Concilium 36.3, released 4 December 1963.}

Decree Ad Gentes: On the Mission Activity of the Church, released 7 December 1965.

8 A similar trend occurs in the Orthodox and Eastern Catholic Churches in the decline and fall of the Soviet Block. For discussions of Eastern Christianity in the postsocialist era, see Roudometof et al. (2005) or Naumescu and Naumescu and Mahieu (2008).

9 For a discussion of exactly why good anthropologists should, in that era, sublimate Christianity in the field, see Schapera (1938) quoted in (Robbins 2004, p. 28). 
The Anthropology of Christianity becomes particularly 'self-conscious' when that Anthropology engages in studying the Christian Other purposefully, being aware of the shared history, theory and terminology. As Keane expresses it:

I find that the topic [of Sumbanese Christianity] has allowed me to address a wide range of theoretical problems that have long provoked me. Moreover, it has allowed me to do so in conversation with religious believers who are hardly likely to grant me special authority, and who speak from within a tradition that has helped shape the vocabulary of social thought in which I work. (Keane 2007, p. 28)

The relationship between Anthropology as a discipline and Christianity as an enterprise of missionary and theological exploration is startlingly close (Sahlins 1996; Davies 2002; Cannell 2005, 2006; Robbins 2006; and from a different angle, Milbank 1990). Christianity is, perchance, the most recursive subject (apart from Anthropology) for Anthropology to study. Asad (1993) genealogy of Anthropology's use of the term 'religion' draws out the specifically Christian notion behind its usage. Whereas many draw on Asad (1993) Genealogies of Religion (e.g., Cannell 2006) to illustrate the correlation between Anthropology and Christianity, it is important to stress that Asad sees not only an influence from Christianity, but 'a specific Christian history' to the view which 'appears to anthropologists today to be self-evident' (Asad 1993, p. 42). This specific history is one which came through the Reformation and, consequently, to make explicit something implicit in Asad's genealogy: The anthropological view of religion is a largely Protestant one, which would not be recognised by the 'early Christian Fathers or medieval churchmen' (Asad 1993, p. 45; see also (Hann 2011)). Because of this situated relationship through the course of colonial expansion and missionary exploration, the anthropological view of religion, at least in Anglophonic Anthropology, it is also startlingly Anglican ${ }^{10}$. Confronting the subject from which much of Anthropology's own tool box was borrowed, anthropologists are met with the curious problem that in a more intense way than normal, Anthropology simultaneously accepts ideas central to Christianity yet rejects the system as a whole.

This simultaneous acceptance of analytical framework from Christianity and the rejection of the religious system as a whole produces within Anthropology a curious issue of semantics, which in turn has methodological impact on the discipline's understanding of Christianity. If, following Asad, 'religion' is a product of Christianity, what good does it then do for Anthropology to call Christianity a 'religion'? Maurice Bloch (2002) has spent some effort removing 'religion' from the disciplinary lexicon for the violation it causes when deployed against non-Christian 'religions'; here I ask a similar question with regard to the epistemological value of using Christianity's own terminology back upon itself. The problem is compounded when Anthropology begins to carry out the cross-areal comparison for which Robbins (2007) calls. Some (e.g., Roman Catholicism) are happy to use and be known as a religion; others (e.g., Evangelical Protestantism) are adamant that Christianity 'is a relationship, not a religion' (for a fuller discussion of this, see Chapter 4 of (McIvor 2016). The degree of difference is apparent again, and possibly more so, when comparing Western (that is those heavily influenced by Augustine and the Latin Fathers) and Eastern (that is those heavily influenced by the Greek and Syriac Fathers) Christianity. Hann and Goltz, in the introduction to their edited volume on Eastern Christians, caution of the 'basic distortion' which can occur when the East is approached in 'narrow Western terms' (Hann and Goltz 2010, p. 11). Bloch, Asad, Cannell, and Hann and Goltz-each in their own way—ask

10 Boylston (2013) critiques Hann $(2007,2011)$ complaint against the particularly Protestant bias in Anthropology of Christianity, saying that this view 'fails to account for the vast and growing influence of charismatic and evangelical religious practice across the globe'. I agree with Boylston in recognising the growing role of global charismatic and evangelical influences, but think it worth pointing out that the recognition of the international Local Churches in the Anglican Communion (from Lambeth 1968 and 1978) was a major influence in the growth of, what in the Anglican Communion is called, the Global South. 
Anthropology to be cognisant of the epistemological heritage and the analytical appropriateness of the theological and analytical terms with which Anthropology engages the ethnographed other.

\section{Theology and Ethnography}

In a 2006 article, Robbins maps out three ways in which Anthropology may fruitfully read Theology ${ }^{11}$. Here I examine Robbins' model in the context of current trends in the field and suggests two further means by which Anthropology may fruitfully engage with theology. First Robbins' groundwork is outlined, then consideration is given to practices which go beyond that model. The section ends considering Hann and Goltz's call to address Eastern Christians in Eastern terms (that is, in their own terms). The subsequent section pursues this line, looking at the literature of Eastern Christianity.

In Robbins' article 'Anthropology and Theology: An Awkward Relationship?' he outlines 'three possible ways anthropology might engage theology' (Robbins 2006, p. 285). The first, already discussed above, is 'the role of theological ideas in its [that is, Anthropology's] own formation' (Robbins 2006, p. 286). The second is to read Theology 'as data that can inform us about the particular Christian culture that produced it' (Robbins 2006, p. 286). This mode of reading theology may be best exemplified in Harding (2000) work on Fundamentalists in the United States. In looking at the linguistic and political ideologies of the 'Moral Majority', Harding highlights how Fundamentalist Christians make use of biblical texts, along specific kinds of theological interpretations. Robbins then uses the rest of the article to discuss the differences in which the two disciplines address a topic that interests them both: that of Otherness. Anthropology, for its part, says Robbins, is quite adept at discovering and describing lived differences; theologians, on the other hand, 'mock anthropologists' in their ability to assert the fundamental nature of perceived differences and, most poignantly, convince their readers to 'let these differences transform their lives' (Robbins 2006, p. 288). In other words, theologians manage to impact wider society in ways anthropologists, of this era, fail to achieve. This is key for Robbins, who sees in Theology's success a challenge to Anthropology to find a way once again to 'show the world how to find hope for real change' without God (Robbins 2006, p. 293). This sort of relevance is something, he asserts, that has not happened in at least the preceding twenty years (Robbins 2006, p. 289). Taken together, Robbins suggests Anthropology read Theology as historical data concerning itself, as a historical artefact of the cultural other, and as an example of successfully deployed theory concerning the 'other'. While each of these are worthwhile ways in which to read theology, they do not, arguably, go far enough in recognizing the role of $\mathrm{T} /$ theology in Christian communities.

Scott 2005, 2007, 2013), in his work among Arosi Christians in the Solomon Islands, presents what here will be listed as a fourth means to read theology. He chooses the term ethno-theology to stand for 'the constructive theological speculations of indigenous Christians' (Scott 2007, p. 35), a practice done by both lay and clergy alike (Scott 2005, p. 102). For Scott, indigenous Christians are actively involved in the process of theological thought, and as such theology is an element of the fieldsite in need of consideration. Liana Chua (2012) also follows this approach and in both their work the active role of (multiple) theological formulations can be seen. While Scott's work tends to keep its focus on local productions of theology, showing, for example, how indigenous mythological personages (2007) and places (2013) are re-imagined within the theological frame of Christianity, Chua (2012) work highlights

11 On the whole, capitalisation is used to speak of the discipline, and the lower-case form is given to denote the more informal, and often quotidian practice. This follows roughly the distinction between great and little traditions (Redfield 1952), however neither in the London community nor in the Athonite monastery were the people in anyway 'unlettered' (Redfield 1952, p. 42). As such, there are often greater or lesser degrees of Theology within theology. Anthony F. C. Wallace also outlines how 'a codified and official mythology (Bible, Koran, and so on)' and 'less elaborated auxiliary texts (theology, metaphysics, history, ethics, and so on)' are integrated through 'extremely elaborate processes of symbolic interpretation' and become what he terms 'substantive beliefs', 'which are expressed not only in myths but also in the very lexicon of the people' (Wallace 1966, p. 74). The orthographic form 'T/theology' is used when both the disciplinary and the folk forms are being spoken of explicitly. 
how 'non'-indigenous theologies (what I call capital T-Theology), such as Anglican, Roman Catholic, and Charismatic practice come to inflect village life in different ways: through both formal teaching (sermons, school) and practice (liturgy, song, conversation). Both great and little tradition T/theology, then, can be read within an ethnography as a cultural artefact seen to impact social and cultural development in the lived world. As is suggested above working from Hann and Goltz' definition of theology, theology is an inherently social thing. It is not, to borrow Latour (2005) language, outside the network, but is rather something within society. It is even a means of being social, and part of the cultural quality of Christianity. As was evident throughout my research, theology-as a set of cultural categories of understanding and practice of and with God-is an active element within the value judgements, decision-making processes, and mode of life of many Orthodox Christians.

The cultural quality of Christianity is a central concern of Robbins' monograph Becoming Sinners, wherein he seeks to critique wider anthropological discourse for being 'unable to see Christianity as cultural' (Robbins 2004, p. 30). Rather than simply evidence of contact, Christianity's reception by local communities, Robbins argues, should be taken as part of local culture, which he defines as 'a system of categories and values with its own coherence' (Robbins 2004, p. 30). If one is to read this at face value, Christian $\mathrm{T} /$ theology seems also to fit the definition, or at least be a prominent part of a larger local cultural system. Accordingly, Robbins proceeds to use Theology as evidence in advancing his social critique. Though not using the technical terms, Robbins cites charismatic Pneumatology (Theology of the Spirit) and Ecclesiology (Theology of the church and its structure), saying that this 'cultural content of this form of Christianity is crucial to its spread' (Robbins 2004, p. 33). In light of his appeal to the codified Theology of charismatic Christianity as a global phenomenon in order to explain Melanesian religious practice, it is curious that he does not admit the fourth way for Anthropology to read $\mathrm{T} /$ theology in his later work.

Following Scott, Chua, and Robbins, I argue that T/theology should be read as part of ethnography. This is akin to Robbins (2006) second role (as an artefact produced by culture), but carries a quite substantial methodological difference, admitting $\mathrm{T} /$ theology as an active set of 'symbolic interpretations' (Wallace 1966) which are part of the 'categories and values' of any particular Christian culture (Robbins 2004). Robbins suggests $\mathrm{T} /$ theology may provide data concerning the culture that produced it, and no doubt it does. But this kind of folklorist approach loses the fact that often theology is a dynamic process that not only is produced by the culture, but also produces the culture, and engages as a social force within the culture (cf. (Das 1984)). Du Boulay (2009), Boylston (2012), and Antohin (2014) each demonstrate how theological principles of Orthodoxy (Greek and Ethiopian) permeate every aspect of quotidian life. ${ }^{12}$ Anthropology's tendency to avoid deep engagement with $\mathrm{T} /$ theology is a tendency to reify its perceived sacredness. Reading theology as part of an ethnography is a timely analytical move within social scientific study of religion for which there is disciplinary precedence in, for example, Evans-Pritchard (1937) approach to Azande witchcraft belief as a culturally acting logic. Likewise, in the Anthropology of Islam, Hoffstaedter (2013) has demonstrated the important role of theology in the success and political implications of NGO intervention. ${ }^{13}$ Such a position can be affirmed from two different theoretical positions.

The first argument for admitting $\mathrm{T} /$ theology as a key ethnographic object suggests that to view $\mathrm{T} /$ theology as something separate and distinct follows the same modernist perception that says that clean distinctions such as 'nature' and 'culture' or 'human' and 'non-human' are valid and true. As such, theology should not be maintained as a reified category separate from sociality, but rather, it

12 (Asad 1993, pp. 27ff), in his use of Louis Dumont, establishes a similar understanding of religion as a social 'all-embracing consideration' wherein medieval religion is seen to be 'pervading or encompassing other categories' (Asad 1993, p. 28). (Robbins 2004, p. 2) also recognizes the quotidian impact of theological teaching in the self-construction of Urapmin Christians as sinners. Bruno Latour's work on religion (Latour 2013) also addresses this in Catholicism.

13 Antohin (2014) makes a similar, though less theologically detailed, claim regarding the success of NGOs in Orthodox Ethiopia. 
must be considered within the same 'hybridity' that Latour $(1991,1993)$ frames 'actor networks' (2005). The second position is to follow Bakhtin and affirm the dialogical quality that theology must have as part of the 'multi-voicedness' (Bakhtin 1984) in which the Orthodox Christian person finds herself. In this regard, T/theology (both codified and 'little') is part of the context within which the self acts and relates. Bakhtin, in discussing the types of dialogue seen in the work of Dostoevsky, summarizes his work saying:

each type [of dialogue] has numerous varieties which we have not touched upon at all. But the principle of construction is everywhere the same. Everywhere there is an intersection, consonance, or interruption of rejoinders in the open dialogue by rejoinders in the hero's internal dialogue. Everywhere a specific sum total of ideas, thoughts, and words is passed through several unmerged voices, sounding differently in each.... the object is precisely the passing of a theme through many and various voices, its rigorous and, so to speak, irrevocable multi-voicedness and vari-voicedness. (Bakhtin 1984, p. 265, emphasis original)

In this way both Latour and Bakhtin provide images of an assemblage of the lived world wherein multiple participants have voice (Bakhtin) or agency (Latour). Both analytical models can work to understand the ethnographic phenomenon wherein theology is seen to exist within the social (and cultural) frame of Christian communities, such that not only should Anthropology and other social sciences, with (Keane 2007, p. 29), acknowledge Christianity to be a 'social fact', but also acknowledge Christian T/theology to likewise be such.

Taking seriously the cultural saliency of theology brings about the fifth way for ethnographic research to engage with theology (Scott 2005; Chua 2012), and returns to the discussion above concerning terminology. As discussed above-following Asad (1993), Bloch (2002), and Cannell (2006) argument-Anthropology has taken a good number of terms and analytical models from the European Christianities alongside which the discipline developed. It has also borrowed a number from the ethnographed communities. Hau (Mauss 1967) and mana (Marett 1909) are just two terms that come to us from indigenous 'theologies' (or the rough equivalent thereto). (See also Robbins 2013 review article for a discussion concerning this type of scholarship.) There is, however, an historically important-though I argue analytically invalid-distinction between these 'indigenous theologies' and the theological tradition(s) of Christianity. As highlighted in the first part of this paper, there has been a hesitancy toward engaging Christianity as an ethnographic subject, and as Robbins (2006) points out, the hesitancy toward ethnographic engagement with the 'elite' of any context continues to influence this tacit rejection of Christian $t /$ Theology. So, while anthropology has built its analytical empire on the foundation stones of what I am calling 'indigenous theologies', it still rejects critical ethnographic engagement with the theologies indigenous to Christian communities.

If we are to follow in this tradition established from early in social scientific enquiry, it is necessary that an Anthropology of Eastern Christianity be willing to critically engage with categories and values indigenous to Eastern Christianity's cultural logic. Having a distinct history and Theology, eastern forms of Christianity do not exhibit the prominent themes witnessed by those in the anthropological discussion (Hann and Goltz 2010, p. 7; Hann 2011). Hann asks if even Bloch (2011) work on 'the blob' is not itself the product of 'Western Protestant bias', which privileges 'individualism and inner states' (Hann 2012). Against Anthropology with a Protestant bias, Hann does not provide a comprehensive picture of the alternative- that is, what an Anthropology of Eastern Christianity in Eastern terms would look like. He does, however, offer recurrent themes, including: continuity (Hann and Goltz 2010, p. 7; Hann 2011, p. 18)—contra Robbin's understanding of Christianity as a religion of 'rupture' $(2003,2007)$; the 'Orthodox theological anthropology' concerning humans as ikons of God (Hann and Goltz 2010, p. 12; Hanganu 2010); and de/materialisation (Hann 2011). These three 'eastern' qualities rang true throughout my research. However, to claim that 'continuity' in Eastern Christianity does not mean 'rupture' is entirely unhelpful as an analytical trope; as I argue below, when engaging in dialogue with eastern Theological perspectives, 'rupture' - though it becomes something radically different in the context of continuity-may still be a helpful analytical framework and point of cross areal comparison. 
The task, then, is to take seriously Hann and Goltz (2010) call to address Eastern Christianity in Eastern terms. The difficulty, from an analytical perspective, is that giving privilege to claims and instructions offered to the ethnographer by informants often produces apparent contradictions. In interviews with informants, the quest for 'Eastern terms' often gave rise to diverse and even disparate results. However, within the diversity of expressions, a near-constant trend emerged, wherein people would direct conversations and interviews back to the Liturgy as an explanatory model for wider social and religious transformation. It is in pursuing an understanding of what the liturgy is and how it operates as a model for diverse and endless interpretation, that we come to the argument at hand here, concerning the relationship of theology and ethnography. In an Eastern Christian context, ethnography must, at least, engage liturgical theology and should engage in reading theological discourse, too.

Insofar as the discipline is only willing to engage a cultural Other with recourse to existing schema of analytical tools, disciplinary discussion will stagnate. If, however, the discipline is willing to critique its own analytical tools in the face of a new Other (e.g., modes of religiosity (Naumescu 2007)) and incorporate new analytical tools offered by the Other (e.g., kenosis (Naumescu 2010)), then the discipline may move forward. The dialogue, then, between theology and ethnography is a necessary step in the progression of social scientific research. While I am not able to expand a full-length ethnography here (see Timothy), in this paper, I sketch out one short ethnographic example of the interplay of continuity and rupture within Eastern Orthodox practice. Before addressing this ethnographic vignette, I briefly review the key aspects of 'rupture' in the anthropological literature and the concept of 'suddenly' in the work of Orthodox bishop and theologian Alexander Golitzin (2001).

\section{On Rupture, Discontinuity, and Suddenly}

Joel Robbins discusses Christianity as a religion of 'rupture' (2003, 2004, 2007). In his own ethnographic fieldwork in Papua New Guinea, he sees a sharp discontinuity in the lives of the individuals and the community at large since the introduction of charismatic Christianity. In a move towards a more purposeful comparative Anthropology of Christianity, Robbins suggests the issues of rupture as a predominant aspect of Christianity. He says:

Christianity represents time as a dimension in which radical change is possible. It provides for the possibility, indeed the salvational necessity, of the creation of ruptures between the past, the present, and the future. The nature of such change is modeled first of all in Christianity's relation to its own past, for it represents itself as having made a decisive break with the Judaism from which it sprang and as having inaugurated a wholly new epoch of divine-human interaction. (Robbins 2007, pp. 10, 11)

For Robbins, Christianity's soteriological narrative needs rupture. To be saved, one must first be saved from something and secondarily that saving is drastic, a 'radical discontinuity' (Robbins 2007, p. 11). This is true, Robbins claims, both for the institution as a whole as it broke from first century Judaism and became a predominantly Gentile movement under Paul's leadership; and on an individual level, most notably in Paul's own personal narrative on the road to Damascus. There is also an awaited rupture, in the millenarian anticipation for the establishment of a new order in the second coming of Christ.

Robbins' reading of Paul and Urapmin Christianity is convincing and makes sense of the situation he encountered. But as a cross-areal paradigm of comparison (something which he calls for in the same 2007 article) it has its limits. Much of the adult population among the Urapmin church remember life before Christ. They have personal narratives of conversion, and the way of life shifted noticeably, and their orientation toward the outside populations and future imaginings also are noticeably different. But this form of Christianity, an outgrowth of the historical trajectory highlighted above, is very young. Less than a generation old among the Urapmin, it is the product of a late 20th Century missionary outgrowth of a mid-20th Century revivalist Charismatic movement. Very different personal narratives are seen among those in traditions that are hundreds and thousands of years old. 
Hann and Goltz (2010) have, rightly, critiqued Robbins' claim, pointing out that while this may be true of the Pentecostalism in which Robbins is situated, it is hardly the case for those Eastern Christianities that have had a continuity of liturgy and custom for well over a millennium (see also Stewart 1991; Hann 2007). In many Christianities, continuity, not rupture, is the greater discourse. Rather than simply break from Robbins, however, I find a dialogue with him much more fruitful. Such a dialogue brings to light some of the paradigmatic discontinuities between Western, and particularly post-Latin, Christianity and that seen in the Eastern traditions.

Robbins (2007) grounds his argument in the conversion of Saul along the road to Damascus. In this story, Saul is traveling in the noonday when 'suddenly' ${ }^{\prime 4}$ a blinding light surrounds him and from it speaks the voice of Christ. Out of this encounter, the newly minted Apostle Paul emerges, and goes to meet and join the Christians, rather than hunt and kill as was his former intent. Marking the radical discontinuity between the Saul and the Paul, Robbins sees this biographical rupture as archetypical of the Christian experience-both personally and communally.

There are serious problems with applying Robbins' critique to Christianity broadly, as Hann and Goltz have reminded us. Yet, even within Eastern Christianity there may be something to Robbins' basic idea, one much more profound than even Robbins could have anticipated.

St Paul's conversion on the road to Damascus is, without a doubt, central to Orthodox Christianity and the shaping of its ethos. 'Rupture', however, never appears in the account. What appears is 'suddenly', or ' $\hat{\xi} \xi \alpha \varphi \vee \eta \sigma^{\prime}$ [eksaiphnes]. This word is the subject of an article by bishop and scholar Alexander (Golitzin) of Toledo, wherein he argues that 'suddenly' is a recurrent word used within the New Testament and early Greek fathers. Throughout its usage, it has ties 'to Christ, to light, to heavenly ascent, and to the liturgies of both the angels and the Church' (Golitzin 2001, p. 489). He follows the implication of the word further, tracing the Syriac equivalent, men shelya, or 'from silence' (Golitzin 2001, p. 489), and points out that the 'shelya' 'is usually connected in Christian Syriac

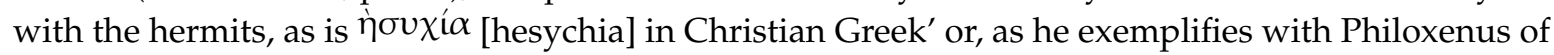
Mabbug, it is used 'to signify the divine being or essence' (Golitzin 2001, p. 490). In this way, Golitzin argues that 'suddenly' may be best seen as a bilingual pun, at once suggesting Christ, light, liturgy, hesychasm (holy silence), and the very essence of God, depending on the 'resonances' and 'intentions and associations' (Golitzin 2001, p. 490) within the (con)text.

Particularly in the Syriac theological reading of 'from silence' there is something akin to Robbins' anthropological reading of 'rupture', even of 'discontinuity'. But it is of a very different vein. Robbins does suggest a certain perpetuity of rupture (a continuous discontinuity?) within Christianity, such that the memory of rupture is 'preserved in Christian tradition' (Robbins 2007, p. 11), but the parallel within Orthodoxy is quite different. In the same article, Golitzin explores the use of suddenly within the epistles of Dionysius the Areopagite. Golitzin summarizes Dionysius' Christology as follows:

God truly gives Himself, the Areopagite states in Epistle II, and truly deifies, but while He is Himself the deifying gift, $\theta \varepsilon$ o $\pi$ o

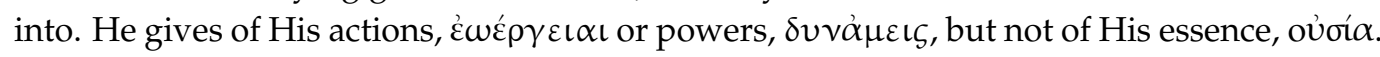
Epistle IV makes clear the source of this gift of divine energy or power. It is Christ. In Jesus, Dionysius tells us, transcendence and immanence (here $\dot{\alpha} \pi \hat{o} \varphi \alpha \sigma \iota \varsigma$ and $\kappa \alpha \tau \dot{\alpha} \varphi \alpha \sigma \iota \varsigma$, respectively) have met and been joined. Those things, he goes on, 'which are affirmed of Jesus' love for humanity preserve the force of transcendent negation'. (Golitzin 2001, pp. 484-85)

I will return to the notion of apophatic and kataphatic ( $\dot{\alpha} \pi \hat{\varphi} \varphi \alpha \sigma \iota \sigma$ and $\kappa \alpha \tau \dot{\alpha} \varphi \alpha \sigma \iota \sigma)$ shortly; but, first, consider the Orthodox fusion of transcendence and immanence. The Christian relation to the divine is, from the Eastern Orthodox perspective, immediate and intimate even though it is also distant and

14 See Acts 9.3 or 22.6 for the Scriptural source for this account, and the word 'suddenly'. 
otherworldly. This paradox is resolved, Dionysius asserts, by 'Jesus' love for humanity', something that is ultimately exemplified within the Christian narrative in the incarnation and crucifixion. Christ's kenosis ('emptying') can then be described as 'the philanthropy of Christ' - an act wherein 'the super-essential has proceeded out of its hiddenness to become manifest to us' (from Epistle III of Dionysius as seen in (Golitzin 2001, p. 486). In other words, it is the act of Christ breaking forth onto the scene of human history which is understood to resolve the incommensurability, making the transcendent immanent. This is the rupture of Orthodox Christianity, and it is a discontinuity that reorders the cosmos, making a new continuity.

This sort of 'trans-immanent' presence, Dionysius continues, is a mystery wherein ' $\mathrm{He}$ is also hidden, both after the manifestation and, to speak more divinely, even within it' (Golitzin 2001, p. 486). Here we return to the apophatic and kataphatic. Golitzin translates these as 'transcendence and immanence', though they are, within theological discourse, often simply transliterated or translated as 'the way of negation' and the way of 'affirmation' (e.g., (Ware 1979, p. 14, 122)). While apophatic theology speaks of what God is not (e.g., ineffable, invisible, immutable) kataphatic theology speaks of what God is (e.g., love, good, eternal). The first speaks of the transcendent divine, the second the immanent and knowable divine. Ware makes the point that these 'coexist', 'are complementary', and affirms that 'each strengthens the other' (Ware 1979, p. 122). Golitzin, drawing on the Areopagite, argues that they are fused, and have become joined in Christ. Thus, much like something veiled, the divine, as Christ, is both shown and concealed.

The collapse of analytical opposites is, as seen in Naumescu (2007), something common in Eastern Christian modes of religiosity. The slippage-intentional and self-veiling-in the theological concepts and the manifestation of Christ produces an important possibility for how rupture may exist in Orthodox Christianity. I now turn to an ethnographic account of Orthodox liturgical practice in order to demonstrate how this theological insight may illuminate anthropological enquiry.

\subsection{Interruption and Temporality}

St Æthelwald's is a small parish that meets in a rented building in East London. Each Sunday morning the clergy and a few lay leaders arrive early to arrange the Orthodox temple within a building that, throughout the week, is used by two Protestant denominations and a few commercial ventures. (For a longer discussion of this transformation, see Carroll 2017a) Once the temple items are arranged, but before the service starts, the priest, Fr Theophani, prays the cannon of preparation before the ikonostasis (ikon screen), greeting in turn the ikons of Christ, the Theotokos, John the Baptist and St Æthelwald. Completing this, the priest returns into the Sanctuary to vest. When he first arrives in the morning, he lays out his vestments on a set of three chairs arranged as the 'seat of judgment', which are set up behind and facing the altar. Coming now to vest, he blesses each item in turn before putting it on. They are a light silk brocade. As he moves, the fabric catches the light, showing an interlocking lattice, with the Greek, equilateral crosses filling each roundel. After vesting, he puts on his pectoral cross, and after a couple tries has it laying correctly. He fidgets with the cross throughout the service, as it turns itself around, or flops off to the side, Fr Theophani moves it back in place, and at times holds it still to keep it from moving. Once fully vested, he turns to wash his hands in a small basin of water, and dries them on a towel kept for that purpose.

Having completed the two parts of personal preparation, he then goes to prepare the gifts (that is, the bread and wine for the Eucharist). He approaches the table of preparation (the prosthesis, $\pi \rho 0 \theta \eta \sigma \iota \varsigma^{\prime}$, a setting forth'), located to the north side of the altar, behind the holy table. As he crosses from the washing basin to the prothesis table, he recites the following prayer:

Make ready, O Bethlehem, for Eden hath been opened for all. Prepare O Ephratha, for the tree of life hath blossomed forth in the cave from the Virgin; for her womb did appear as a spiritual paradise in which is planted the divine Plant, whereof eating we shall live and not die as Adam. Christ shall be born, raising the image that fell of old. Thou has redeemed us from the curse of the Law, by thy precious Blood; nailed to the cross and pierced by 
the spear, thou has poured forth immortality upon mankind. O our Saviour, glorify thee. (AOCANA The Antiochian Orthodox Christian Archdiocese of North America)

By the end of the prayer, he is standing before the table of prothesis. At the centre is the bread, the prosfora $(\pi \rho \circ \sigma \varphi \sigma \rho \alpha ́$, offering or gift) wrapped in a cotton bag made specifically for this purpose. To the left are a set of veils stacked under the service books for the morning liturgy and the proskomedia ( $\pi \rho \circ \sigma \kappa о \mu \iota \delta \eta$, 'an offering' - this term and prosthesis are, in this context, interchangeable). The diskos

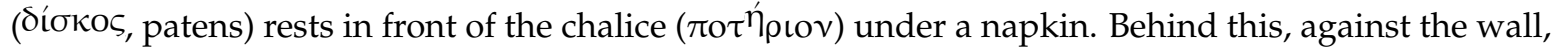
is an ikon of the nativity. To one side is a cup and saucer, a candle, a thermos of hot water, a vial of fortified sweet wine, a vial of water, a stack of loose slips of paper with the names of loved ones brought by the people, and a plain knife. Above the prosfora, between it and the chalice, rest the asterisk (a 'star', metal frame to protect the bread) and the utensils of the sacrifice: a spoon and a spear.

Fr Theophani greets the table with three half metanias ${ }^{15}$, with each, he reaching to below his knee, rises and crosses himself. He then removes the napkin which covers the chalice, folds it, and along with the first of the two spoons, gives it to the subdeacon who takes it and places it on the right (south) side of the altar. He then kisses the asterisk (or 'star cover'), the diskos and the chalice. These are the metal implements that will house the bread, wine, and water: what will eventually be made into the Eucharistic body and blood. These are objects that only the clergy may touch.

After venerating the implements of his next task, the priest lifts the prosfora, which is a white, leavened wheat loaf. The prosfora is marked on the top crust with a Greek cross of five equally proportioned squares, the centre three each have the letters I $\Sigma$ X $\Sigma$ NIKA (Jesus Christ Conquers) ${ }^{16}$. To the left is one large triangle, to the right are nine small triangles. Each section is used for a specific aspect of the commemorations. The centre, once removed, is spoken of as 'the lamb' (o $\dot{\alpha} \mu \nu$ ó $\sigma)$. The large triangle represents the Theotokos, who bore Christ. Some traditions speak of the whole loaf as an image of the Theotokos, for it is from her that Christ took his flesh. The nine small triangles on the right come to represent the nine orders of saints. These are the angels, the apostles, the holy fathers, the martyrs, the ascetics, the unmercinary healers, the ancestors of Christ and the festal saints, and the saint whose liturgy is about to be celebrated (either John Chrysostomos or Basil the Great). The lower portion is used to commemorate the living and the dead, and the top portion, along with the entire left over bread, is cut and used as antideron ('instead of the gifts'), given to the faithful after the liturgy.

Lifting the loaf in his left hand, the priest holds the spear in the right. Three times he crosses the loaf with the tip of the spear, each time saying 'In remembrance of our Lord and God and Saviour Jesus Christ.' Setting it back on the cutting board, he cuts along the four edges of the centre square, first with the spear, but finishing the incisions with the plain knife. First on the right side of the lamb, while he says 'As a sheep led to the slaughter', then on the left, saying, 'And as a blameless lamb before its shearers is dumb, so he opened not his mouth'. These two vertical cuts he extends with the knife down to the bottom of the cross.

Across the top of the lamb, he cuts with the spear, saying, 'In his humiliation, justice was denied him', and along the bottom, 'Who can describe his generation'. Then taking the knife, he slices along the bottom crust of the loaf, freeing the lamb and the bottom most piece of the cross. Removing the bottom piece out of the way, he uses the spear to lift the lamb out of the loaf, saying, 'For his life is

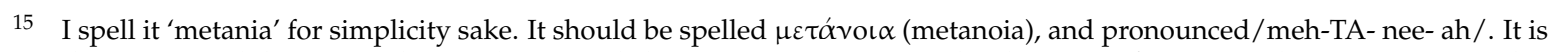
the same word that is transliterated into English as metanoia, meaning the changing of one's mind or 'repentance'. This connection is often lost on the lay religious observer, but is a usual item of instruction. The act of bowing in a metania should be an act of metanoia.

16 Often the Greek is spelled with a lunate sigma (thus: IC XC NIKA), the form given here reflects what was used on the prosfora in question. See (Du Boulay 2009, p. 150) for a similar discussion of bread, though one which highlights some of the subtle differences between local practices, particularly in terms of which section of the bread is used for the remembrances of the living and the dead. 
taken up from the earth'. Cleaning the lamb of any crumbs, he places it on the diskos. He turns in upside down and, again with the spear, cuts a cross in the bottom such that the four quadrants of the lamb are held together only by the top crust. As he cuts, he recites, 'Sacrificed is the Lamb of God, who taketh away the sin of the world, for the life of the world and its salvation. At thee crucified, O Christ, tyranny was laid low and the power of the enemy was trampled underfoot. Glory to thee, for neither an angel nor a man, but the Lord himself hath saved us.' Returning it right, he pokes it with the spear on the left and right sides, 'One of the soldiers pierced his side with a spear, and at once there came out blood and water; and he who saw it hath borne witness, and his witness is true'. With these words, he takes up the vials of wine and water, removes the corks and decants them into the chalice, reciting 'Blessed is the union of thy holy things, always, now and ever, and unto ages of ages. Amen.' ${ }^{17}$

Having set down the glass vials and returned the corks, Fr Theophani again picks up the spear. With three incisions, he lifts the triangle commemorating the Theotokos out of the loaf, as he says 'In honor and memory of the most blessed and glorious Lady the Theotokos and ever-virgin Mary, through whose intercessions do thou accept, O Lord, this sacrifice upon thy most heavenly altar.' He then places it to the left of the lamb. Then one at a time, he removes the nine small triangles and with the commemorations for the appropriate saints there commemorated, places them on the other side of the lamb.

Throughout these prayers and the commemoration of the saints, the priest calls to mind past and future events. The sacrificial language of the ritual is framed within larger, sempiternal, scales of time. ${ }^{18}$ These remembrances are not simply the memory of historical events, but ones of participation as the word-anamnesis-means to call to mind so as to participate. In this liturgical act is the production of kairotic time of heavenly, salvific history. The liturgy is, in the words of Orthodox priest and theologian Alexander Schmemann (2000), 'the chalice of eternity'.

After the nine orders of the saints, Fr Theophani was distracted by one of his spiritual sons who had come asking for him. He first sent one of the servers to let the young man know that he was unavailable, but then he went to speak with him himself. His absence from the table is unusual, but demonstrates a few things. Heaven, as it were, can be put on pause. This relates to conceptions of temporality as already discussed above. The proskomedia is a divine, heavenly service, taking place on God's 'most heavenly altar' - and as such, the service is eternal. But it is fitted into the quotidian temporalities (Eliade (1954) 'concrete time' or Benjamin's [2003, but written in 1940] 'homogeneous, empty time') of earth. That which is done here on the side table in a London temple is modelled after the archetype of heaven. So, if a disturbance happens, the service may be put on hold and then picked up from the exact place. ${ }^{19}$

After conversing with his spiritual son, Fr Theophani returns to the service, and begins the commemorations of the people. He picks up exactly where he left off, needing only to flip the service book to the correct page as his billowing phelonion had rustled the pages in passing.

The commemorations are for the living and dead persons who are remembered because of their relation to the priest or other individuals who request their names to be remembered. In some places

17 It is important to note here that most priests would be serving with a deacon, and most service books assume both roles will be filled. While the parish had had a deacon, by the time I was granted access to witness what occurred in the Altar for research purposes, he had been ordained priest and moved to a different parish. As such, Fr Theophani sometimes says things marked for a deacon, depending on need. It is also his practice to modernise the English, favouring 'has' for 'hath', and so on.

18 For a fuller discussion of the Orthodox Theology of time, see (Gallaher 2013).

19 On this subject, two notes: (1) When the Ottomans took 'Agia Sophia in Constantinople, it was mid liturgy. The liturgy was stopped, but Greeks understand this to be simply a pause. When 'Agia Sophia is restored to the Church, the liturgy will be completed. This is a subject of pious hope and apocalyptic prophecy. (2) There is a book (Mironko 2008) a priest had just acquired at the Deanery Conference in June 2011 that addressed what should be done in case of various accidents and disasters during the Liturgy. In the event that the building be found to be on fire, the priest is to calmly remove the elements and necessary utensils to a safe location and continue the service as if there had been no interruption. On one hand, this is absurd (and caused much amusement amongst clergy and laity alike). On the other, heaven cannot be stopped it can only be delayed. 
the stacks of paper, simply filled with lists of names, may become unruly. Even here with the small stack, those serving often have difficulty shuffling the papers and keeping them all together. Following the instruction of his bishop, Fr Theophani commemorates only those who are Orthodox. Some bishops allow non-Orthodox to be commemorated, and in his capacity as the chaplain of a nearby educational institution (under a different bishop) he is allowed to commemorate anyone. As such, the stack of papers on the lower right hand corner of the table include many names which he cannot commemorate at the present service.

Taking the lower section of the loaf, he turns it over in his hand and makes a cutting motion with the spear lengthwise along the bottom of the piece. With each movement, he reads one of the names, letting the crumbs loosed from the bread fall onto the lower section of the diskos. Having read dozens of names, a small pile of crumbs forms on the lower half of the diskos. Using the flat edge of the spear as a scraper, the priest ensures that the pile of crumbs is kept separate from the larger pieces. A horizontal line is created here, with those glorified above the partition, and those living and dead below it.

At this point, the subdeacon lifts a lit sensor toward Fr Theophani. The priest blesses it, lifting his hand toward the sensor, and makes the sign of the cross over it, saying 'Blessed is our God, always, now and ever, and unto ages of ages. Incense we offer unto thee, O Christ our God, as a savour of spiritual sweetness which do thou receive upon thy most heavenly altar and send down upon us in return the grace of thine all-holy Spirit.' He lifts the asterisk, opens it into the ' $X$ ' shape, and holds it over the incense, shaking it slightly while he says, 'The star came to rest over the place where the young child was.' He then kisses it, and places this on the diskos, creating a small cage-like covering for the lamb and elements of commemoration. Next he grabs one of the veils, and likewise holds it over the incense. Holding one section in each hand, he wraps it around the chains of the censor and makes a small open and close motion, fluttering the fabric around the sensor. Along with jingling the bells, which are attached to the sensor chain, this also causes the smoke to move in puffs, rising in small dense clouds rather than in a single pillar as it would normally. As he does this, he says 'The Lord is King, he is clothed with majesty; the Lord is clothed with strength and he hath girt himself. For he established the world which shall not be shaken.' Kissing it, he covers the diskos, letting the cloth rest atop the asterisk. Taking the second veil, he does the same, this time saying 'Thy virtue has covered the heavens, O Christ, and the earth is full of thy praise.' Kissing it, he rests it upon the chalice. Next, taking the large veil (the aër, $\dot{\alpha} \eta_{\rho}$, literally 'air'), he repeats the sensing as before, saying 'Shelter us, O God, in the shelter of thy wings; drive away from us every enemy and foe; make our life peaceful; O Lord, have mercy on us and on thy world, and save our souls, for thou art good and lovest mankind, and art a merciful God.'

The priest then takes the sensor, and the subdeacon kisses his hand as he lets go. The priest stands before the table of proskomedia, and senses the offering, saying thrice, 'Blessed art thou, O our God, who art thus pleased. Glory to thee, always, now and ever, and unto ages of ages. Amen.' After returning the sensor to the subdeacon, he prays:

'O God, our God, who didst send forth the heavenly Bread, the Food of the whole world, our Lord and God Jesus Christ, our Saviour and Redeemer and Benefactor, blessing and sanctifying us: Do thou thyself bless this oblation, and receive it upon thy most heavenly altar. Remember, as thou art good and lovest mankind, those who brought this offering and those for whom they brought it; preserve us blameless in the celebration of thy divine mysteries, for sanctified and glorified is thine all-honorable and majestic name of the Father and of the Son and of the Holy Spirit, now and ever, and unto ages of ages. Amen.

Then,

Glory be to Thee, Christ our God and hope, glory to Thee. May Christ, our true God, who was born in a cave and laid in a manger for our salvation, through the prayers of his most holy Mother; of the glorious Prophet and Forerunner John the Baptist; of those 
Saints whose memory we celebrate today; of our father among the saints, John Chrysostom, Archbishop of Constantinople, and of all thy saints, have mercy upon us and save us, for he is good and loves mankind.

This final form is a signature end to all services; they begin with an exclamation of blessing, and end with a commemoration of the saints. These commemorations always begin with Christ, and name him according to the service or the festal season. This epithet, "who was born in a cave and laid in a manger for our salvation' is used here in Prothesis as well as at Christmas, making the link between the service of proskomedia and the Christmas feast explicit. This action of being born, spoken from the first to last prayer of Prothesis is salvific in itself, and clothes the entire process of preparation as a metaphor of Christ's years of preparation for his eventual role of public ministry.

Finally, the priest kisses the aër over the diskos, over the chalice and on the corner saying 'Holy God: the unoriginate Father; Holy Mighty: the co-eternal Son; Holy Immortal: the all-holy Spirit. O Holy Trinity: Glory to thee.'

Finishing this process, the priest takes the censor and censes the Holy Altar and the Vessels. He moves in an anticlockwise fashion about the Holy Table, starting with the western side. Across the table, toward the four cardinal points, he swings the censor three times, letting the smoke and jangle of bells fill the Altar with fragrance and noise. He does so saying: 'In the tomb with thy body, with thy soul in hell as God, in paradise with the thief, on the throne with the Father and the Spirit; Christ, thou art infinite, filling all things.'

He then exits the Altar through the Holy Doors and censes the entire temple, going out among the congregation to sense the people and ikons. He starts with those ikons on the ikonostasis, then moves up the aisle, across the back of the nave to sense the Festal Ikon positioned at the main doors. Returning, he senses the people and ikons along the other (north) side of the main isle. He then senses the ikonostasis again, and enters the Altar. Having completed this he, the congregation and the building are ready to begin the Liturgy.

The service, like all Orthodox liturgical worship, weaves together grand movements in cosmological time, linking points on the calendar (such as Christmas to each morning liturgy) and drawing those present into the participation within times past and future. This quality of participating in something outside chronological time opens up a reappraisal of rupture.

\subsection{Rupture}

Hann (2007); Hann and Goltz (2010) has argued that the analysis of Christianity as a religion of rupture (Robbins 2003; 2007; Lampe 2010) is faulty, in that while it might be true of the kinds of Pentecostalism studied by Robbins, it is not true of Eastern Christianities. Rather, Eastern forms of Christianity are characterised more, Hann (2007) argues, by continuity (Stewart 1991). Curiously, (Buchli 2010a, p. 197), writing in the context of Ancient Christianity, characterises 'Christian technologies of the prototype' - such as ikonography—as 'a radical rupture' from pre-existing pagan modes of 'presencing the im-material'. Robbins, for his part, identifies Christianity as a religion of 'rupture', specifically in terms of 'the creation of ruptures between the past, the present, and the future' both communally and individually (Robbins 2007, pp. 10-11). Both Buchli and Robbins identify Christianity as being a religion characterised by rupture, however Buchli does so in terms of technological and Robbins in terms of temporal means. Hann and Goltz (2010) critique of Robbins is along the lines of temporality, arguing that Eastern Christianities are characterised not by rupture but by continuity. Juxtaposing Buchli's observations concerning technology, however, helps resolve a tension in Hann and Goltz's critique. Hann and Goltz are correct in assessing Eastern Christianities as having a temporality characterised by continuity-this is certainly true in the context of Orthodox Christianity, wherein the notion of kairos (the eternal moment) suggests that, ecclesiologically speaking, there is no such thing as the passage of time. However, as Buchli shows in his two works comparing Christian ikons and rapid manufacturing (Buchli 2010a, 2010b), the ikon allows for what he calls 'propinquity', or 'degrees of nearness in different registers' (Buchli 2010a, p. 186), between the prototype (the saint) 
and the viewer. This propinquity, he goes on to say, allows for tactile interaction between the saint and the devotee, following Aristotelian traditions of haptic vision (Buchli 2010a, p. 275; 2010b, p. 191). Buchli, in both pieces, repeatedly speaks of the visual and physical aspects of propinquity, such that 'propinquity is achieved through visual and physical co-presence' (Buchli 2010a, p. 189). He leaves aside, however, the possibility of social co-presence.

I have written elsewhere of the intersubjective relationships formed between devotees and saints, via relics (Carroll 2016b) and ikons (Carroll 2015, 2016a). These relationships are akin to Zhao (2003) 'copresence', Lévy-Bruhl's 'participation' (Pina-Cabral 2013), and Lowenthal (1985) 'tangibl[ity]' of relics. Particularly with Lévy-Bruhl's 'participation', which Pina-Cabral links to Zhao's idea of 'copresence', there is the explicit possibility that these intersubjectivities may form via 'material aspects of their world (things)' (Pina-Cabral 2013, p. 266). As such, 'propinquity' is not sufficient to capture the tactile 'participation' and 'copresence' made possible by items such as relics and ikons. The 'rupture' that Buchli speaks of, then, is a technology wherein the sacred may become visually, physically, and-I add-socially copresent. Sacred material, in an Orthodox context, does not simply make the holy 'near', but, as my informants stress, the holy 'is at hand'.

Take this technological rupture back into the context of temporality. Hann and Goltz are interested in the continuity of Eastern Christianities on the large scale of the longue durée of millennia. On this scale, there the kairos temporality is, yes, continuous. However, taken on the scale of lived religion, moments of kairos may break into moments of-and be interrupted by comments of-chronos (chronological time). Just as the temple spoken of in the ethnographic passage above is arranged in a building used throughout the week by other religious and secular communities within London, so the paternal care of the priest for his spiritual son may pause the sacred time of the liturgical services. Similar to Benjamin's 'messianic time', which 'comprises the entire history of mankind in a tremendous abbreviation' (Benjamin 2003, p. 398), the scale and nature of kairotic time interposes into and about mundane, chronological time such that the two modes of time break forth suddenly into each other. The priest's is a moment of mundane rest taken in the midst of what is otherwise a physically and taxing exercise in the temple-as-ikon-of-universe. On this small scale, examining the theology implicit within the liturgical traditions, one can also see how Orthodox Christianity comes into the home via ikons, holy water, and even herbs used in the liturgy (Carroll 2017b). These sacred objects come into the home and make sacred space within a mundane space. This as a technological rupture both from the pre-Christian pagan technologies (Buchli 2010a, 2010b) and from the immediate context (domestic goods, and the urban environment), but it is also a rupture in temporality as it makes a space of the eternal, the kairotic, alongside the chronological cycles of family life.

For Robbins, the temporal rupture of Christianity appears on two levels. It is both true of the founding of Christianity, as a break from Judaism, and true of individual life narratives (Robbins 2003, 2007). However, the temporalities spoken of here are of a different scale. What appears here is the phenomenon of material registers of the sacred being employed to make sacred spaces and moments within the mundane. The use of holy oil, the drinking of holy water, the veneration of an ikon and the lighting of candles are all material modes of rupture wherein the Orthodox Christian can be seen to 'participate' (in a Lévy-Bruhlian sense) with the sacred. As such, what is proposed here is that rupture is a useful paradigm with which to understand Eastern Christianities, too, albeit it is a different form of rupture.

In this context, the sacred is not only seen to 'come to us without conscious aim or effort' (Lowenthal 1985, p. 245), but also to draw other materials and people into living with the sacred. The point of Orthodox liturgical ritual is to come to live with God, not in an ecstatic or transcendent manner, but rather to allow, through various material engagements, the holy to break through into the mundane aspects of life. That is, to return to the work of His Grace Alexander of Toledo, to have the collapse of the apophatic and kataphatic, transcendence and immanence. One way this is achieved is through the distribution of the secondary relics, holy oil, and the circulation of ikons such that the copresence with the holy may rupture forth into everyday life. 


\section{Conclusions}

Malcolm Haddon, in an article on the Hare Krishna theology and practice of proselytism, or sankirtana, asks the 'awkward methodological question' as to whether his 'ethnography "of" sankirtana is also a "form of" sankirtana?' (Haddon 2013, p. 251). Here, I must ask a similar question, not concerning proselytism, but concerning the interpretive opinions concerning the meaning of liturgical symbols: that is, 'mystagogy'. In the preparations made before the table of prosthesis there is, in the account given above, a point of difference made between how Fr Theophani performs the practice at the parish versus in his role as chaplain elsewhere. Such differences abound, and at times the interpretation around the service may be quite different: the preparation of the host, for example, may be symbolic of the birth of Christ, but the use of the veils over the chalice and diskos also lends itself to be seen as a vesting services for the host-as-priest. In one such case, when a visiting priest prepared prosthesis according to this other tradition, Fr Theophani, while not disagreeing with the priest, distanced himself from the priest's interpretation of the service. Any mystagogy, I was told, was fine for personal devotion as long as it does not impede the basic interpretation of the Liturgy and the consecration and distribution of the Eucharist. In writing about, and offering an anthropological interpretation of, Orthodox Christian symbols, my ethnography sits as an anthropological mystagogy. Haddon (2013) answers his question saying that yes, his writing is proselytism, but is so, he says, of necessity, and there are no negative repercussions to that fact. In my case, I would likewise say that aspects of my work can be read as anthropological mystagogy. This is, on one level, addressing Eastern Christianity in Eastern terms (Hann and Goltz 2010), but it is also using indigenous tropes to speak of the ethnographic other (Wagner 1981). This use of indigenous tropes is what Wagner speaks of as 'self-aware' Anthropology (Wagner 1981, pp. 15, 16), which he likens to the impressionist painters heightened focus on the mode of brushstrokes that they employed. Haddon-working from Benjamin (1996), Asad (1993), and Harding (2000)—highlights the aspect of this sort of anthropological work as 'cultural translation' (Haddon 2013). It is this sort of anthropological translation work that I see needed in the dialogue between the social sciences and theology, and much work is needed in order to move the disciplinary conversation toward becoming 'self-aware'. This self-aware Anthropology should also be done in dialogue with, not just dialogue about, indigenous communities. Particularly in the case of the mystagogy of anthropological work like this present paper, dialogue and critique with indigenous theologians and cultural theorists may prove highly insightful and beneficial to both the discipline and the researched community. To do this properly, indigenous tropes need to be used as analytical frames-as is done here with, for example, transcendence and immanence; but so too should indigenous modes of thought be used in anthropological analysis. As such, the discipline should move toward using indigenous rhetorical techniques, such as allegory. More work needs to be done on not only the cultural categories among ethnographic communities, but also on the indigenous modes of logical reasoning, of which several have already been examined (Shore 1996), and apply it as an analytical model within anthropological discourse.

Acknowledgments: I would like to thank my interlocutors in the field, especially the man I here call Fr Theophani and the other members of the parish community in East London. I would also like to thank Joel Robbins, Victor Buchli, and Méadhbh McIvor for their helpful comments on various versions of this article. The research upon which this paper is in part based was funded by the Paleologos Graduate Scholarship of the Greek Orthodox Archdiocese of America. All errors are my own.

Conflicts of Interest: The author declares no conflict of interest.

\section{References}

Antohin, Alexandra. 2014. Expressions of Sacred Promise: Ritual and Devotion in Ethiopian Orthodox Praxis. Ph.D. Thesis, University College London, London, UK.

AOCANA (The Antiochian Orthodox Christian Archdiocese of North America). 2010. The Liturgikon: The Book of Divine Services for the Priest and Deacon. Grand Rapids: Dickinson Press. 
Asad, Talal. 1993. Genealogies of Religion: Discipline and Reason of Power in Christianity and Islam. Baltimore: John Hopkins University Press.

Bakhtin, Mikhail. 1984. Problems of Dostoevsky's Poetics. Minneapolis: University of Minnesota Press.

Barker, John. 1992. Christianity in Western Melanesian ethnography. In History and Tradition in Melanesian Anthropology. Edited by James Carrier. Berkeley: University of California Press, pp. 144-73.

Benjamin, Walter. 1996. The task of the translator. In Walter Benjamin: Selected Writings, Volume 1: $1913-1926$. Edited by Marcus Bullock and Michael Jennings. Cambridge: Harvard University Press, pp. 253-63, First published 1923.

Benjamin, Walter. 2003. On the concept of History. In Walter Benjamin: Selected Writings, Volume 4: 1938-1940. Edited by Michael Jennings. Cambridge: Harvard University Press, pp. 389-400.

Bialecki, Jon, Joel Robbins, and Naomi Haynes. 2008. The Anthropology of Christianity. Religion Compass 2: 1139-58. [CrossRef]

Bloch, Maurice. 2002. Are religious beliefs counterintuitive? In Radical Interpretation in Religion. Edited by Nancy Frankenberry. Cambridge: Cambridge University Press.

Bloch, Maurice. 2011. The blob. Anthropology of This Century. Available online: http:/ /aotcpress.com/articles/ blob/ (accessed on 1 June 2011).

George Bond, Walton Johnson, and Sheila Walker, eds. 1979. African Christianity: Patterns of Religious Continuity (Studies in Anthropology). New York: Academic Press.

Boylston, Tom. 2012. The Shade of the Divine: Approaching the Sacred in an Ethiopian Orthodox Christian Community. Ph.D. Thesis, London School of Economics, London, UK.

Boylston, Tom. 2013. Orienting the East: Notes on Anthropology of Orthodox Christianities. Available online: http:/ / anthrocybib.net/ (accessed on 28 May 2013).

Brandes, Stanley. 1980. Metaphors of Masculinity: Sex and Status in Andalusian Folklore. Philadelphia: University of Pennsylvania Press.

Buchli, Victor. 2010a. Presencing the im-material. In An Anthropology of Absence: Materializations of Transcendence and Loss. Edited by Mikkel Bille, Frida Hastrup and Tim Flohr Soerensen. London: Springer, pp. 185-203.

Buchli, Victor. 2010b. The prototype: Presencing the immaterial. Visual Communication 9: 273-86. [CrossRef]

Campbell, John. 1964. Honour, Family, and Patronage. Oxford: Clarendon Press.

Cannell, Fenella. 2005. The Christianity of Anthropology. Journal of the Royal Anthropological Institute 11: 335-56. [CrossRef]

Fenella Cannell, ed. 2006. Anthropology of Christianity. Durham: Duke University Press.

Cannell, Fenella. 2010. The Anthropology of Secularism. Annual Review of Anthropology 39: 85-100. [CrossRef]

Carroll, Timothy. 2015. An ancient modernity: Icons and the revitalisation of Britain. In The Spirit of Things: Material Religion in Modern Britain. Edited by Timothy Jones and Lucinda Matthews-Jones. Basingstoke: Palgrave Macmillan, pp. 185-208.

Carroll, Timothy. 2016a. Architectural renovations of body-as-temple. New BioEthics 22: 119-32. [CrossRef] [PubMed]

Carroll, Timothy. 2016b. Im/material objects: Relics, gestured signs, and the substance of the immaterial. In Materiality and the Study of Religion: The Stuff of the Sacred. Edited by Timothy Hutchings and Joanne McKenzie. Abingdon: Routledge, pp. 119-32.

Carroll, Timothy. 2017a. Axis of Incoherence: Engagement and Failure Between Two Material Regimes of Christianity. In Material Culture of Failure: When Things Do Wrong. Edited by Timothy Carroll, David Jeevendrampillai, Aaron Parkhurst and Julie Shackelford. London: Bloomsbury Press, pp. 157-78.

Carroll, Timothy. 2017b. The ethics of Orthodoxy as the aesthetics of the local church. World Art, 7, Published electronically Apr 10. [CrossRef]

Timothy, Carroll. Forthcoming; Orthodox Christian Material Culture: Of People and Things in the Making of Heaven. Abingdon: Routledge.

Christian, William. 1972. Person and God in a Spanish Valley. Princeton: Princeton University Press.

Chua, Liana. 2012. The Christianity of Culture: Conversion, Ethnic Citizenship, and the Matter of Religion in Malaysian Borneo. New York: Palgrave Macmillan.

Comaroff, Jean, and John Comaroff. 1991. Of Revelation and Revolution: Christianity, Colonialism, and Consciousness in South Africa. Chicago: University of Chicago Press, vol. 1. 
Das, Veena. 1984. For a folk-theology and theological anthropology of Islam. Contributions to Indian Sociology 18: 294-300. [CrossRef]

Davies, Douglas. 2002. Anthropology and Theology. Oxford: Berg.

Douglas, Mary. 1966. Purity and Danger: An Analysis of Concepts of Pollution and Taboo. London: Routledge.

Douglas, Mary. 1993. In the Wilderness: The Doctrine of Defilement in the Book of Numbers. Ann Arbor: University of Michigan Press.

Douglas, Mary. 1999. Leviticus as Literature. New York: Oxford University Press.

Douglas, Mary. 2004. Jacob's Tears: The Priestly Work of Reconciliation. Oxford: Oxford University Press.

Du Boulay, Juliet. 2009. Cosmos, Life and Liturgy in a Greek Orthodox Village. Edited by Evia Limni. Evia: Denise Harvey Publisher.

Durkheim, Emile. 1915. The Elementary Forms of the Religious Life. London: George Allen \& Unwin Ltd.

Eliade, Mircea. 1954. Cosmos and History: The Myth of the Eternal Return. New York: Harper Torchbooks.

Engelke, Matthew. 2002. The problem of belief: Evans-Pritchard and Victor Turner on 'the inner life'. Anthropology Today 18: 3-8. [CrossRef]

Matthew Engelke, and Matt Tomlinson, eds. 2006. The Limits of Meaning: Case Studies in the Anthropology of Christianity. New York: Berghahn Books.

Evans-Pritchard, Edward E. 1937. Witchcraft, Oracles and Magic among the Azande. Oxford: Clarendon Press.

Gallaher, Brandon. 2013. Chalice of Eternity: An Orthodox Theology of time. St Vladimir's Theological Quarterly 57: 5-35.

Golitzin, Alexander. 2001. Revisiting the 'Sudden': Epistle III in the Corpus Dionysiacum. Studia Patristica 37: 482-91.

Haddon, Malcolm. 2013. Anthropological proselytism: Reflexive questions for a Hare Krishna ethnography. The Australian Journal of Anthropology 24: 250-69. [CrossRef]

Hanganu, Gabriel. 2010. Eastern Christians and religious objects: Personal and material biographies entangled. In Eastern Christians in Anthropological Perspective. Edited by Hann and Goltz. Berkeley: University of California Press, pp. 230-65.

Hann, Chris. 2007. The Anthropology of Christianity per se. Archives Européennes de Sociologie 48: $383-410$. [CrossRef]

Hann, Chris. 2011. Eastern Christianity and Western social theory. In Erfurter Vorträge zur Kulturgeschichte des Orthodoxen Christentums. Erfurt: University of Erfurt, vol. 10.

Hann, Chris. 2012. Personhood, Christianity, Modernity. Anthropology of This Century. Available online: http: / /aotcpress.com/articles/personhood-christianity-modernity/ (accessed on 1 February 2012).

Hann, Chris, and Hermann Goltz. 2010. Introduction: The Other Christianity? In Eastern Christians in Anthropological Perspective. Edited by Hann and Goltz. Berkeley: University of California Press, pp. 1-29.

Harding, Susan Friend. 1991. Representing fundamentalism: The problem of the repugnant cultural other. Social Research 58: 373-93.

Harding, Susan Friend. 2000. The Book of Jerry Falwell: Fundamentalist Language and Politics. Princeton: Princeton University Press.

Hoffstaedter, Gerhard. 2013. Islam and Freedom of Religion: Anthropology, Theology and clashes of universalisms in contemporary Malaysia. The Australian Journal of Anthropology 24: 270-89. [CrossRef]

Howell, Brian. 2007. The repugnant cultural other speaks back. Anthropological Theory 7: 371-91. [CrossRef]

Ingham, John. 1986. Mary, Michael, and Lucifer: Folk Catholicism in Central Mexico. Austin: University of Texas Press.

Keane, Webb. 2007. Christian Moderns: Freedom and Fetish in the Mission Encounter. Berkeley: University of California Press.

Lampe, Frederick. 2010. The Anthropology of Christianity: Context, contestation, rupture, and continuity. Reviews in Anthropology 39: 66-88. [CrossRef]

Latour, Bruno. 1991. Technology is society made durable. In A Sociology of Monsters? Essays on Power, Technology and Domination. Edited by John Law. Sociological Review Monograph; London: Routledge, pp. 103-31.

Latour, Bruno. 1993. Ethnography of a 'high-tech' case: About Aramis. In Technological Choices: Transformation in Material Cultures Since the Neolithic. Edited by Pierre Lemonnier. London: Routledge, pp. 372-98.

Latour, Bruno. 2005. Reassembling the Social: An Introduction to Actor-Network-Theory. New York: Oxford University Press.

Latour, Bruno. 2013. Rejoicing: Or, The Torments of Religious Speech. Cambridge: Polity Press. 
Leenhardt, Maurice. 1947. Do Kamo: Person and Myth in the Melanesian World. Chicago: University of Chicago Press.

Lowenthal, David. 1985. The Past is a Foreign Country. Cambridge: Cambridge University Press.

Makrides, Vasilios N. 2012. Orthodox Christianity, Modernity and Postmodernity: Overview, Analysis and Assessment. Religion, State and Society 40: 248-85. [CrossRef]

Marett, Robert R. 1909. The Threshold of Religion. London: Methuen \& Co. LTD.

Mauss, Marcel. 1967. The Gift: Forms and Functions of Exchange in Archaic Society. New York: WW Norton \& Company, Inc., First published 1923.

McIvor, Méadhbh. 2016. To Fulfil the Law: Evangelism, Legal Activism, and Public Christianity in Contemporary England. Ph.D. Thesis, London School of Economics and Political Science (LSE), London, UK.

Milbank, John. 1990. Theology and Social Theory: Beyond Secular Reason. Oxford: Blackwell.

Mironko, Arkadiusz. 2008. Regarding Accidents and Defects Occurring During the Liturgy, and how to Proceed. Waymart: Saint Tikhon's Press.

Naumescu, Vlad. 2007. Modes of Religiosity in Eastern Christianity: Religious Processes and Social Change in Ukraine. Berlin: Lit Verlag.

Naumescu, Vlad. 2010. Le vieil homme et le livre: La crise de la transmission chez les Vieux-Croyants. Terrain 55: 72-89. [CrossRef]

Vlad Naumescu, and Stéphanie Mahieu, eds. 2008. Churches In-Between: Greek Catholic Churches in Postsocialist Europe. Berlin: Lit Verlag.

Pina-Cabral, João. 2013. The two faces of mutuality: Contemporary themes in Anthropology. Anthropological Quarterly 86: 257-75. [CrossRef]

Pop, Simion. 2011. Eastern Orthodox Christianity as anthropological object: Concepts and methodological considerations. Studia UBB Sociologica 56: 93-108.

Redfield, Robert. 1952. The primitive world view. Proceedings of the American Philosophical Society 96: 30-36.

Robbins, Joel. 2003. On the paradoxes of global Pentecostalism and the perils of continuity thinking. Religion 33: 221-31. [CrossRef]

Robbins, Joel. 2004. Becoming Sinners: Christianity and Moral Torment in Papua New Guinea Society. Berkeley: University of California Press.

Robbins, Joel. 2006. Anthropology and Theology: An Awkward Relationship? Anthropological Quarterly 79: $285-94$. [CrossRef]

Robbins, Joel. 2007. Continuity thinking and the problem of Christian culture: Belief, time, and the Anthropology of Christianity. Current Anthropology 48: 5-38. [CrossRef]

Robbins, Joel. 2013. Afterword: Let's keep it awkward: Anthropology, Theology, and Otherness. The Australian Journal of Anthropology 24: 329-37. [CrossRef]

Victor Roudometof, Alexander Agadjanian, and Jerry Pankhurst, eds. 2005. Eastern Orthodoxy in a Global Age: Tradition Faces the 21st Century. Walnut Creek: AltaMira Press.

Sahlins, Marshall. 1996. The sadness of sweetness: The native anthropology of Western cosmology. Current Anthropology 37: 395-428. [CrossRef]

Schapera, Isaac. 1938. Contact between European and Native in South Africa (cont.): 2. In Bechuanaland. In Methods of Study of Culture Contact in Africa. Edited by Bronislaw Malinowski. Oxford: Oxford University Press, pp. 25-37.

Scott, Michael. 2005. 'I Was Like Abraham': Notes on the Anthropology of Christianity from the Solomon Islands. Ethnos: Journal of Anthropology 70: 101-25. [CrossRef]

Scott, Michael. 2007. The Severed Snake: Matrilineage, Making Place, and a Melanesian Christianity in Southeast Solomon Islands. Durham: Carolina Academic Press.

Tomlinson, Matt, and Debra McDougall. 2013. 'Heaven on Earth' or Satan's 'Base' in the Pacific? Internal Christian Politics in Dialogic construction of the Makiran Underground Army. In Christian Politics in Oceania. ASAO Studies in Pacific Anthropology. Tomlinson, Matt, and Debra McDougall. Oxford: Berghahn Books, pp. 49-77.

Shore, Bradd. 1996. Culture in Mind: Cognition, Culture, and the Problem of Meaning. Oxford: Oxford University Press.

Schmemann, Alexander. 2000. The Journals of Alexander Schmemann 1973-1983. Translated by Juliana Schmemann. Crestwood: SVS Press. 
Stewart, Charles. 1991. Demons and the Devil: Moral Imagination in Modern Greek Culture. Princeton: Princeton University Press.

Stott, John. 1975. The Lausanne Covenant-An Exposition and Commentary. Lausanne Occasional Papers; Taiko: Lausanne Committee.

Turner, Victor, and Edith Turner. 1995. Image and Pilgrimage in Christian Culture: Anthropological Perspectives. New York: Columbia University Press, First published 1978.

Visvanathan, Susan. 1993. The Christians of Kerala: History, Belief and Ritual among the Yakoba. Oxford: Oxford University Press.

Wagner, Roy. 1981. Invention of Culture. Chicago: University of Chicago Press.

Wallace, Anthony F. C. 1966. Religion: An Anthropological View. New York: Random House.

Ware, Kallistos (Timothy). 1979. The Orthodox Way. Crestwood: St Vladimir's Seminary Press.

Weber, Max. 2005. The Protestant Ethic and the Spirit of Capitalism. London: Routledge and the Taylor \& Francis e-Library, First published in 1905.

Wilson, Monica. 1971. Religion and the Transformation of Society: A Study in Social Change in Africa. Cambridge: Cambridge University Press.

Zhao, Shanyang. 2003. Toward a taxonomy of copresence. Presence 12: 445-55. [CrossRef]

(c) 2017 by the author. Licensee MDPI, Basel, Switzerland. This article is an open access article distributed under the terms and conditions of the Creative Commons Attribution (CC BY) license (http:/ / creativecommons.org/licenses/by/4.0/). 